\title{
Keeping narcotic drugs at bay
}

The United States has embarked on what seems to be a competition to find the toughest recipe for keeping hard drugs out of reach. But the remedies likely to be most effective may well be overlooked.

NarCoric drugs seem destined to be an issue in this November's mid-term congressional elections in the United States, but nobody is quite sure why. The death in August from cocaine intoxication of a talented college basketball player must have had something to do with this development. So too has the spate of recent publicity for a form of cocaine called "crack" (the active principle without its molecular attachments), said to be more rapidly effective, more addictive and cheaper than the oldfashioned coke of the 1920 s, also recently back in fashion. President Reagan (whose wife has done a valuable job in persuading people that there is a problem to be tackled) has now decreed that "sensitive" federal employees should be tested for the use of drugs (for some of the practical difficulties, see page 285) and, in his folksy way, has provided a urine sample for analysis. (So, too, has vice-president George Bush, while the refusal of the mayor of Atlanta to do so on the grounds of civil liberties may have been a contributory factor to his failure earlier this month to win nomination as a candidate for the US Senate.) Where will it all lead?

There is a danger that Gresham's law, the doctrine that bad money displaces good, will apply. Legislators of all kinds are busy with bills at various stages, with the House of Representatives way out in front. On 11 September, its members (each of whom is up for election in November) endorsed a rag-bag of measures intended to keep narcotics out of the United States which would have the administration do more of what it is doing already, but would also introduce mandatory death sentences for those repeatedly convicted of selling drugs and would require that the US military forces should be used to police the frontiers of the United States with such thoroughness that the illicit import of drugs would be halted in 45 days. The US Senate lags in the race, but seems to have fallen in with the notion that there should be an agreed piece of legislation by November. The administration's own proposals, financially more modest but linked with the scheme for testing federal employees for drug usage, are permissively agnostic on the wilder additions to the sensible parts of the House of Representatives' bill. One way or another, some amalgam of these proposals is almost certain to become law.

\section{Teenagers}

That there is a haunting problem to be tackled is beyond dispute. Although the number of heroin users in the United States appears to have reached a plateau in the past year or so, there are still some 500,000 people in this condition known to the several health agencies concerned with their treatment and rehabilitation (such as it is), or more than twenty times as many as there are AIDS patients. Cocaine seems to be less widely used, but can evidently be addictive and fatal. Crack is especially feared because it has been used among groups of teenagers, although the extent to which the pushers have penetrated this vulnerable part of their market remains unknown. Other industrial nations, or at least the nations of Western Europe, had better take note of the way the wind is blowing in the United States.

What might more moderately be done? One of the surprising features of the past two months of excitement about narcotics in the United States is the degree to which it is uninformed by data. Nobody is much to blame for that, for illicit activities are almost always also ecret. Yet it should be possible to learn more than is known at present about the pattern of drug use in the United States and elsewhere. If, for example, it is true that the recruitment of new heroin addicts has been declining. however great the number still using the drug, it would be valuable to know why. Have people switched to other things, cocaine perhaps? Or have they been influenced by the public education of the past several years? Or are some potential users becoming sensible spontaneously, and if so why? These are the kinds of questions that might have been tackled by the type of social science that became unfashionable in the late 1970s. To the extent that all the proposals now in the legislative mill in the United States advocate that more should be spent on "research", it must be hoped that some of the money will be directed in these constructive directions.

\section{Crisis}

The general nature of the outcome of inquiries such as these is, uncomfortably for those up for re-election, predictably unclear. There can be no simple remedy for the drugs crisis in the United States, and for its lesser images elsewhere, unless it is that the word "crisis" should be prohibited in this connection. If, by magic, the US forces were to do what congressmen wish, and halt the flow of cocaine from Latin America. would not those who must get high go back to marijuana, in the production of which the United States is said now to be half self-sufficient? If some drug-sellers were found, after the incvitable legal delays. to qualify for the death penalty under the rules now being talked of, is there any reason to expect that such a move would deter people now from taking to this unwholesome trade. often under the compulsion of their own addiction? The sad truth is that there can be no quick fix and that the best hope is persistence.

Two particular issues remain. While the US Congress and the administration seem to have set aside the Gramm-Rudman injunction to reduce the budget deficit when planning their fight against drugs, centres for the treatment and rehabilitation of drug-users are too few and inadequately provided; while necessarily the responsibility of state governments, federal support for them could work wonders but comparatively little is now promised. Similarly, the drug-testing programmes promised (some say threatened) by the federal government, themselves formal versions of programmes operated by several large corporations, are specified in strictly negative terms (which is why they are denounced as illibertarian). What is a person's right of appeal against a false positive, for example? And given that the drugs problem is in the broadest sense a social problem, one in which narcotics users may fairly claim to be partly the victims of past neglect, what will be done to help them as well as to punish them (by the sack)? It is not entirely irrelevant that these days the chief overseas sources of the supply of narcotics to the United States are mainly poor farmers in countries that might have expected more past aid programmes than, in the event, they received. 